\title{
Potential use of sewage sludge ash (SSA) as a cement replacement in precast concrete blocks
}

\author{
M. Pérez-Carrión a , F. Baeza-Brotons ${ }^{\mathrm{a}}$, J. Payá ${ }^{\mathrm{b}}$, J.M. Saval ${ }^{\mathrm{a}}$, E. Zornoza ${ }^{\mathrm{a}}$, \\ M.V. Borrachero ${ }^{b}$, P. Garcés ${ }^{\mathrm{a}} \bowtie$ \\ a. Universidad de Alicante (Alicante, España) \\ b. Instituto de Ciencia y Tecnología del Hormigón (ICITECH), Universitat Politècnica de València (Valencia, España) \\ $\bowtie$ pedro.garces@ua.es
}

\begin{abstract}
The present study explored the technological feasibility of re-using sewage sludge ash (SSA) as a Portland cement replacement in commercially manufactured pre cast concrete blocks. The blocks analysed were made to the guidelines laid down in Spain's National Plan for Waste Water Treatment Plant Sludge, 2001-2006, and European Union specifications (CE marking) for such products. Performance was compared in three families of blocks, with 0,10 and $20 \%$ SSA. The findings proved that SSA is apt for pre cast concrete block manufacture and that, in addition to the economic and environmental benefits afforded, its use would improve certain of the properties of conventional block.
\end{abstract}

KEYWORDS: Waste valorisation; CE mark; SSA; precast blocks; concrete

Citation / Citar como: Pérez-Carrión, M.; Baeza-Brotons, F.; Payá, J.; Saval, J.M.; Zornoza, E.; Borrachero, M.V.; Garcés, P. (2014) Potential use of sewage sludge ash (SSA) as a cement replacement in precast concrete blocks. Mater. Construcc. 64 [313], e002 http://dx.doi.org/10.3989/mc.2014.06312

RESUMEN: Uso potencial de ceniza de lodo de depuradora (CLD) como sustitución de cemento en bloques de hormigón prefabricados. El objetivo de esta investigación es estudiar el uso potencial de las cenizas de lodos de depuradora (CLD), como sustitución del cemento Portland en bloques de hormigón prefabricados, de forma que se pueda lograr una revalorización de este material de desecho mediante este procedimiento. La metodología utilizada en este trabajo se rige por las directrices del Plan Nacional Español de Lodos de Aguas Residuales de 2001-2006, y por las exigencias del Consejo Europeo (marcado CE), que es obligatorio para este tipo de productos. Se han utilizado dos niveles de sustitución de cemento (10\% y $20 \%)$, y todos los resultados han sido referidos a las muestras control. Los resultados obtenidos muestran que es posible utilizar una sustitución parcial del cemento por CLD, en la fabricación de bloques de hormigón prefabricados, y por lo tanto, se pueden conseguir beneficios económicos y ambientales, así como la mejora de una serie de propiedades.

PALABRAS CLAVE: valorización residuos; marcado CE; CLD; bloques prefabricados; hormigón

Copyright: (C) 2014 CSIC. This is an open-access article distributed under the terms of the Creative Commons Attribution-Non Commercial (by-nc) Spain 3.0 License.

\section{INTRODUCTION}

The composition of the sewage sludge (SS) generated in waste water treatment plants depends on the pollution contained in the initial waste water and the treatment procedures used. Since water treatment concentrates the pollution present in sewage, the resulting SS contains a wide variety of suspended or dissolved matter, some of which is of agricultural value (organic matter, nitrogen $(\mathrm{N})$, 
phosphorus $(\mathrm{P})$ and potassium $(\mathrm{K})$ and in smaller proportions, calcium $(\mathrm{Ca})$, magnesium $(\mathrm{Mg})$ and other essential plant micronutrients), while other components, such as heavy metals, pathogens and organic compounds, are potentially polluting. This waste must be managed in accordance with principles and policies geared to protecting the environment and human health, which include prioritising prevention over recycling and other types of valorisation, including energy, and establishing the deposit of these materials in sanitary landfills as a last resort (1). SS is normally used in agriculture. The respective legal framework lays down ceiling values for heavy metals and requirements for biological, chemical or thermal treatment, long-term storage or other suitable procedures to significantly reduce the fermentation power in sludge and any health hazards involved in its use in the soil. The legislation further stipulates that plants' nutrition needs must be determined to define fertiliser dosages to prevent any alteration of water or soil quality (2). The most widespread treatment processes for SS, often used in combination, are: mesophilic anaerobic digestion; composting; thermal drying; aerobic stabilisation; chemical stabilisation (with mineral reagents such as iron chloride or lime); dehydration; incineration; and co-incineration in cement plants. Some of these treatments entail drawbacks such as high initial investment and maintenance costs, the need for odour control or vey large sites, or the risk of explosion in processes that generate gas $(3,4)$.

According to a 2010 European Commission study, Spain produces approximately 1.06 million tonnes of sludge yearly, measured as dry matter (5). Such waste commonly ends up in fertilisers $(65-80 \%)$, sanitary landfills $(8-20 \%)$ or incinerators to reduce its volume. Around $4-10 \%$ of the total sludge is incinerated, but the trend is to raise European mean of $20-25 \%(1,5,6)$. In sludge with a $25-30 \%$ solids content, incineration reduces the volume by $90 \%$, greatly facilitating management of this waste. A certain fraction of the energy consumed in combustion or to heat the air to partially dry the sludge is "recovered" in the form of exhaust gases. Some plants have boilers and turbines that generate electric power from those gases,

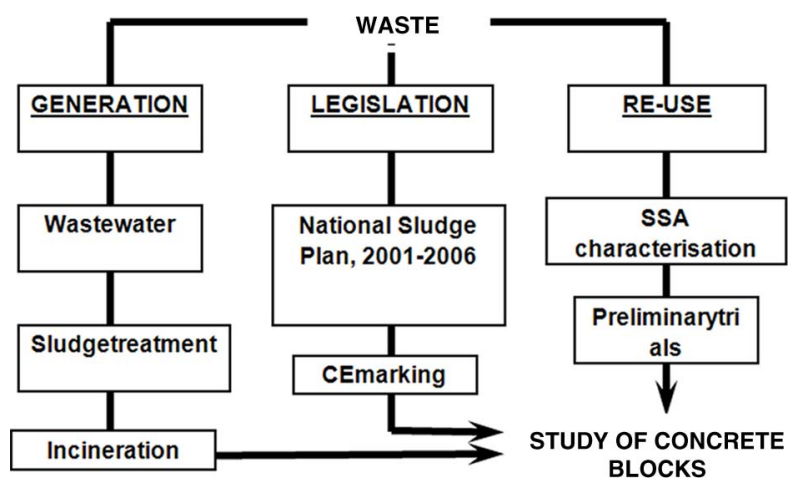

Figure 1. Key questions addressed in the study.

although the power output is fairly small unless the solids content in the sludge is significantly higher than $30 \%(7,8)$. Prior studies showed that SSA can be used in brick manufacture (9-11), as fines in mortars $(12,13)$, to prepare synthetic aggregate (14-17) and as aggregate in hot mix asphalt (18). SSA has likewise been used to produce phosphoric acid (19). Nonetheless, one of its most promising applications is as an admixture in construction mortars or concretes. Previous studies have shown that mortars made with SSA exhibit good mechanical properties (20-22). The improvement observed can be attributed to the pozzolanic activity of SSA $(6,23)$, although recent research on re-used material showed that, compared to other known pozzolans, its pozzolanicity is weak at best (24). SSA fineness has been observed to have a significant effect on both the mechanical strength and workability of concrete (25-27). SSA has also been applied as a lightweight material in thermal and acoustic insulation (28). Studies on its compatibility with a variety of types of cement in connection with mechanical strength $(29,30)$ concluded that given its physical properties, it is apt for inclusion in the preparation of portland cement-based materials. Lastly, environmental questions must also be borne in mind, for sludge ash may contain hazardous compounds $(31,32)$.

The primary aim of the present study was to determine whether SSA would be apt for the production of pre cast concrete blocks, further to Spain's National Plan for Waste Water Treatment

TABLE 1. Chemical composition of sewage sludge ash (wt $\%$ )

\begin{tabular}{cccccccccccc}
\hline $\mathrm{SiO}_{2}$ & $\mathrm{Al}_{2} \mathbf{O}_{3}$ & $\mathbf{C a O}$ & $\mathrm{Fe}_{2} \mathbf{O}_{3}$ & $\mathbf{S O}_{3}$ & $\mathbf{K}_{2} \mathbf{O}$ & $\mathbf{N a}_{2} \mathbf{O}$ & $\mathbf{M g O}$ & $\mathbf{T i O}_{2}$ & $\mathbf{P}_{2} \mathbf{O}_{5}$ & $\mathbf{H}_{2} \mathbf{O}$ & $\mathbf{L O I}^{*}$ \\
\hline 19.2 & 8.9 & 30.6 & 10.0 & 11.1 & 1.4 & 0.8 & 2.7 & 1.0 & 12.3 & 0.5 & 5.1 \\
\hline
\end{tabular}

Proportion of main elements expressed as oxides, obtained with XRD

${ }^{*}$ LOI: Loss on ignition (1 hour at $950^{\circ} \mathrm{C}$ ). 
TABLE 2. Crystalline components in sewage sludge ash

\begin{tabular}{llll}
\hline Mineral & Chemical formula & PDF card & Remarks \\
\hline Quartz & $\mathrm{SiO}_{2}$ & 371497 & Peak 100, majority \\
Anhydrite & $\mathrm{CaSO}_{4}$ & 371496 & Majority peak \\
Calcite & $\mathrm{CaCO}_{3}$ & 050586 & Minority peak \\
Forsterite & $\mathrm{Mg}_{2} \mathrm{SiO}_{4}$ & 340189 & Minority peak \\
Magnetite & $\mathrm{FeO} \cdot \mathrm{Fe}_{2} \mathrm{O}_{3}$ & 190629 & Minority peak \\
Free lime & $\mathrm{CaO}$ & 371497 & Traces \\
Whitlockite & $\beta-\mathrm{Ca}_{3}\left(\mathrm{PO}_{4}\right)_{2}$ & 090169 & Traces (main peak concurrent with anhydrite peaks) \\
\hline
\end{tabular}

Plant Sludge, 2001-2006, and CE marking specifications. SSA valorisation as a component in concrete blocks would be economically, technologically and environmentally beneficial.

This study of SSA addressed three main issues: (a) the generation of waste matter; (b) the applicable legislation; and (c) the study of end product properties relevant to its use. The questions explored in connection with those concerns are shown in the flow-chart in Figure 1.

\section{EXPERIMENTAL}

\subsection{Materials}

The components of the pre cast concrete blocks analysed in this study were tap water, limestone fine and coarse aggregate and CEM I $52.5 \mathrm{R}$ portland cement. The SSA used was produced by a fluidised bed incinerator in a waste water treatment plant at Pine do in the Spanish province of Valencia. The maximum temperature reached at the plant is $800{ }^{\circ} \mathrm{C}$. Table 1 gives the chemical composition of the SSA, obtained with $X$-ray fluorescence (XRF), while Table 2 lists the XRD findings. The SSA was a fine brown powder with a mean particle diameter ranging from 63 to 110 microns. Although X-ray diffraction (XRD) identified a number of crystalline compounds, the SSA was primarily amorphous due to the high temperatures reached during the incineration of the original sewage sludge, which induced thermal activation of its clay content. Ash particles were irregularly shaped and had a specific surface (Blaine method) of approximately $3000 \mathrm{~cm}^{2} / \mathrm{g}$. These properties $(20,21,23,26)$ were indicative of the existence of the pozzolanicity that isessential to the objectives proposed and to the potential use of the ash as a cement replacement. Lastly, a methylene blue test conducted as recommended in Spanish standard UNE 83-130-90 showed that both its organic matter and clay content were low or non-existent.

\subsection{Procedures}

The application of Directive 89/106/EEC and the $\mathrm{CE}$ marking to construction materials and other products is advancing steadily in Europe. To obtain the CE marking, without which products cannot be brought to market, certain minimum safety and quality standards must be met. Consequently, contrary to past practice, no product-specific requirements are established. Rather, manufacturers must guarantee the characteristics of their products, in the case of concrete masonry units, as per Spanish and European standard UNE-EN 771-3. According to these provisions, prior to the introduction of a new product on the European market, a series of initial trials must be run to ensure that its properties meet the manufacturer's specifications and quality and safety standards. The methodology used in the present study was designed along the guidelines set out in those provisions. Table 3 lists the trials established in European standard EN 771-3 for pre cast concrete blocks and the Spanish standards describing the procedures for each that were followed in this study.

In this study, the tests listed in Table 3 were applied to pre cast concrete blocks in which the cement was partially replaced with SSA. The findings were compared to the results for control materials, namely concrete blocks containing no SSA.

TABLE 3. Initial tests required of precast concrete blocks by European standard EN 771-3

\begin{tabular}{ll}
\hline Test & \multicolumn{1}{c}{ Standard } \\
\hline Dimensions & UNE-EN 772-16 \\
Density & UNE-EN 772-13 \\
Compressive strength & UNE-EN 772-1 \\
Configuration & UNE-EN 772-16+ 772-2 \\
Water absorption by capillarity & UNE-EN 772-11 \\
Thermal properties & UNE-EN 771-3 \\
Water vapour permeability & UNE-EN 771-3 \\
\hline
\end{tabular}


TABle 4. Mix proportions (in $\mathrm{kg}$ ) used to manufacture precast concrete blocks

\begin{tabular}{lccc}
\hline Component & $\mathbf{0} \%$ SSA & $\mathbf{1 0} \% \mathbf{S S A}$ & $\mathbf{2 0} \% \mathbf{S S A}$ \\
\hline Fine aggregate & 1002 & 1002 & 1002 \\
Coarse & 501 & 501 & 501 \\
aggregate & & & \\
Cement & 100 & 90 & 80 \\
SSA & - & 10 & 20 \\
Water & 66.8 & 66.8 & 66.8 \\
\hline
\end{tabular}

TAble 5. Precast concrete block dimensions (mm)

\begin{tabular}{lcll}
\hline & Length & Width & Height \\
\hline Control & $397 \pm 1$ & $198 \pm 1$ & $203 \pm 1$ \\
$10 \%$ SSA & $397 \pm 1$ & $198 \pm 1$ & $203 \pm 1$ \\
$20 \%$ SSA & $397 \pm 1$ & $198 \pm 1$ & $203 \pm 1$ \\
\hline
\end{tabular}

The concrete from which the blocks were made was proportioned as shown in Table 4 . The blocks were manufactured in a plant using standard procedures. After a single drop on the consolidation table, the moulds were removed and the blocks were aircured at ambient temperature for 28 days.

\section{RESULTS}

\subsection{Dimensional stability}

Table 5 lists the mean dimensions measured on the precast concrete blocks with and without SSA. Further to those findings, the blocks were classified in EN 771-3 tolerance category D1. D1 tolerance class blocks must measure $400 \mathrm{~mm}$ long, $200 \mathrm{~mm}$ wide and $200 \mathrm{~mm}$ high, with tolerances of +3 to -5 $\mathrm{mm}$ in each dimension. The dimensions of all three families of blocks measured therefore met the requirements for this category. The minor variations with respect to the tolerance category values may be attributed to wear on the moulds. No differences were observed between the control and experimental blocks.

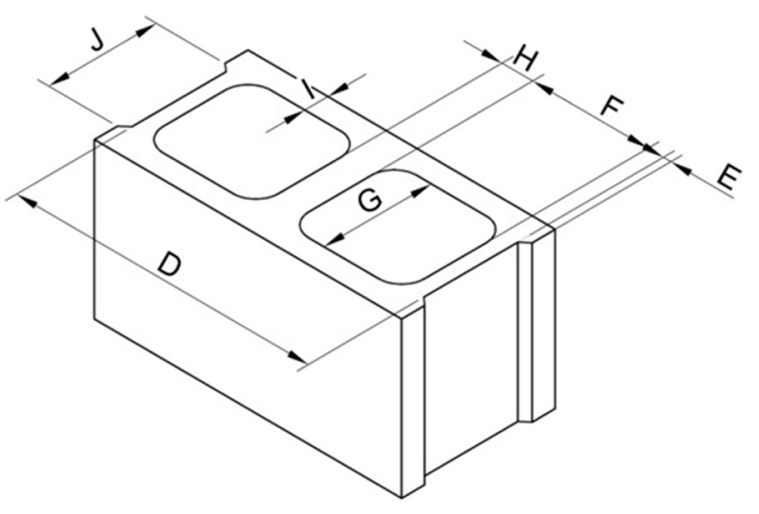

Figure 2. Pre cast concrete block configuration, showing components to be measured.

\subsection{Configuration}

Figure 2 shows the configuration of the pre cast concrete blocks studied. The upper case letters on the figure show the elements whose dimensions must be declared in block specifications. Table 6 lists all the dimensions depicted in Figure 2 for the blocks studied. The subscripts $a$ and $b$ in dimensions $\mathrm{F}, \mathrm{G}, \mathrm{H}$ and I refer respectively to the measurements taken at the bottom and top of the block.

The differences in web and shell width at the top and bottom of the concrete block are the result of the truncated pyramid shape of the inner mould, required to facilitate casting and mould removal. The minimum web and shell width is $25 \mathrm{~mm}$. That minimum dimension is not adversely affected by use-induced wear on the mould prior to replacement (generally after $5 \cdot 10^{5}$ units). On the contrary, wear widens the webs and shells, for the block is the negative of the mould. In other words, the variation in width due to mould use enhances safety.

\subsection{Density}

European standard EN 771-3 stipulates that at least six pre cast concrete blocks in each family have to be tested. Table 7 gives the mean apparent dry and water-saturated density values for each family of blocks, along with the Pearson coefficient, the

TABLE 6. Dimensions measured in the concrete blocks studied ( $\mathrm{mm})$

\begin{tabular}{lccccccccccc}
\hline & D & E & Fa & Fb & Ga & Gb & Ha & Hb & Ia & Ib & J \\
\hline Control & 378 & 10 & 138 & 150 & 126 & 145 & 34 & 25 & 35 & 27 & 119 \\
$10 \%$ SSA & 378 & 10 & 137 & 150 & 127 & 145 & 34 & 26 & 35 & 27 & 119 \\
$20 \%$ SSA & 378 & 10 & 137 & 150 & 127 & 146 & 35 & 26 & 35 & 25 & 119 \\
\hline
\end{tabular}


TABLE 7. Apparent dry and water-saturated density in pre cast concrete blocks

\begin{tabular}{lcccc}
\hline & $\begin{array}{c}\text { Apparent } \\
\text { dry } \\
\text { density } \\
\left(\mathbf{k g} / \mathbf{m}^{\mathbf{3}}\right)\end{array}$ & $\begin{array}{c}\text { Coefficient } \\
\text { of } \\
\text { variation }\end{array}$ & $\begin{array}{c}\text { Water- } \\
\text { saturated } \\
\mathbf{d e n s i t y} \\
\mathbf{( k g / \mathbf { m } ^ { \mathbf { 3 } } )}\end{array}$ & $\begin{array}{c}\text { Coefficient } \\
\text { of } \\
\text { variation }\end{array}$ \\
\hline Control & 2120 & 0.004 & 2290 & 0.003 \\
$10 \% \mathrm{SSA}$ & 2070 & 0.006 & 2250 & 0.007 \\
$20 \% \mathrm{SSA}$ & 2040 & 0.008 & 2210 & 0.004 \\
\hline
\end{tabular}

statistic chosen to determine the repeatability and uniformity of the values observed.

Table 7 shows that the control blocks had the highest density values. The density in the SSA blocks was just $4 \%$ lower than in the controls. Repeatability was high, indicating block uniformity, in both the dry and water-saturated blocks.

\subsection{Compressive strength}

European standard EN 771-3 specifies that manufacturers must declare concrete block compressive strength either: (a) as characteristic compressive strength, $f c$, ( $5^{\text {th }}$ percentile); or (b) as mean compressive strength, $f m,\left(50^{\text {th }}\right.$ percentile). Both items were considered in the present study. The characteristic compressive strength is the strength for the lower 5-per cent fractile, while mean compressive strength is the 50-per cent fractile. Individual block strength (fbi) was determined for both cement replacement rates to calculate these parameters and hence the value to be declared in each case.

Figures 2 to 5 show the results of the statistical analysis of the pre cast concrete block compressive test values, in which the data were assumed to be normally distributed. The blocks containing $10 \%$

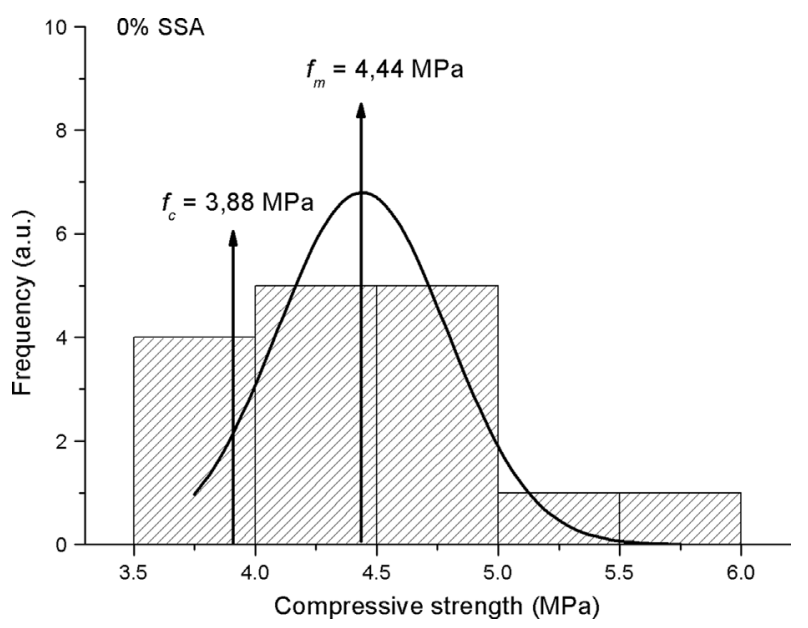

FIgURE 3. Analysis of compressive strength data for pre cast concrete blocks with no SSA.
SSA had a higher $f m$ and $f_{c}$ than the control blocks, while the 20-per cent replacement blocks exhibited slightly lower $f m$ and $f c$ values.

The declared $\mathrm{fm}$ values were $4.44,5.59$ and 4.17 $\mathrm{MPa}$ for the control, 10-per cent replacement and 20-per cent replacement blocks, respectively. In other words, the 10- and 20-per cent SSA blocks exhibited $25 \%$ higher and 5\% lower strength, respectively, than the control.

The declared $f c$ values, in turn, were 3.88, 4.58 and $3.77 \mathrm{MPa}$, respectively, for the control and the 10- and the 20-per cent SSA blocks; i.e., strength in the second was $18 \%$ higher and in the third 3\% lower than in the control.

Figure 6 shows the compressive strength distribution for the precast concrete blocks with and without SSA. As noted earlier, the curves in the figure were obtained by fitting the results to a normal distribution and, in this case, normalising their heights. On the grounds of the shape and position of the curves, the difference between the 0 and $20 \%$ specimens was fairly minor. The blocks containing $10 \%$ SSA, by contrast, exhibited higher strength than both the control and the 20-per cent SSA blocks. A distinction can therefore be drawn between the blocks with the two replacement rates: with $10 \%$ SSA, compressive strength rose significantly, while with $20 \%$, strength would not be enhanced but the blocks would require less cement. Both combinations are consequently possible, and the choice of one or another would depend on the benefit sought: technological (not only greater strength, but a certain reduction in cement consumption) or economic and environmental (nearly the same strength but with considerably lower cement consumption). The standard deviation values found for the samples, which are related to the scatter of the data around the mean and the width of the distribution curve in

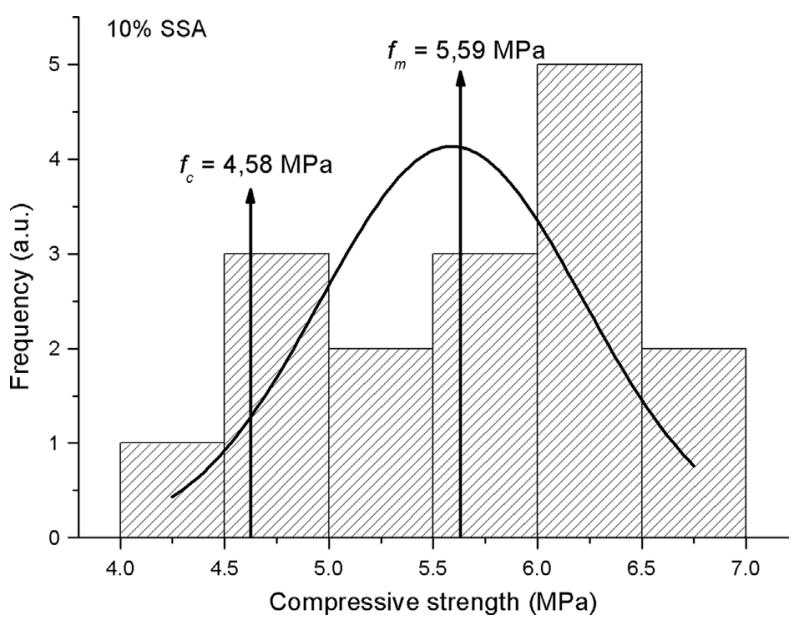

FIGURE 4. Analysis of compressive strength data for pre cast concrete blocks with $10 \%$ SSA. 


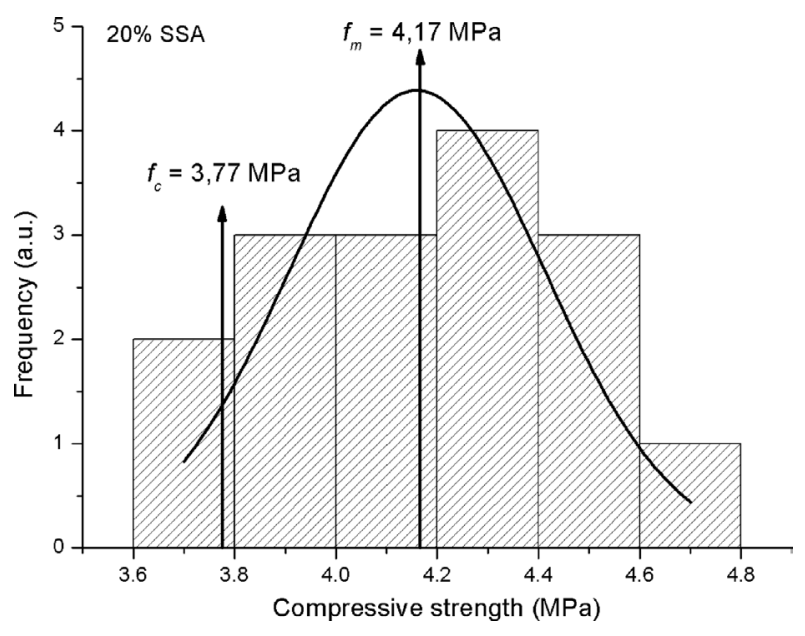

FIgURE 5. Analysis of compressive strength data for pre cast concrete blocks with $20 \%$ SSA.

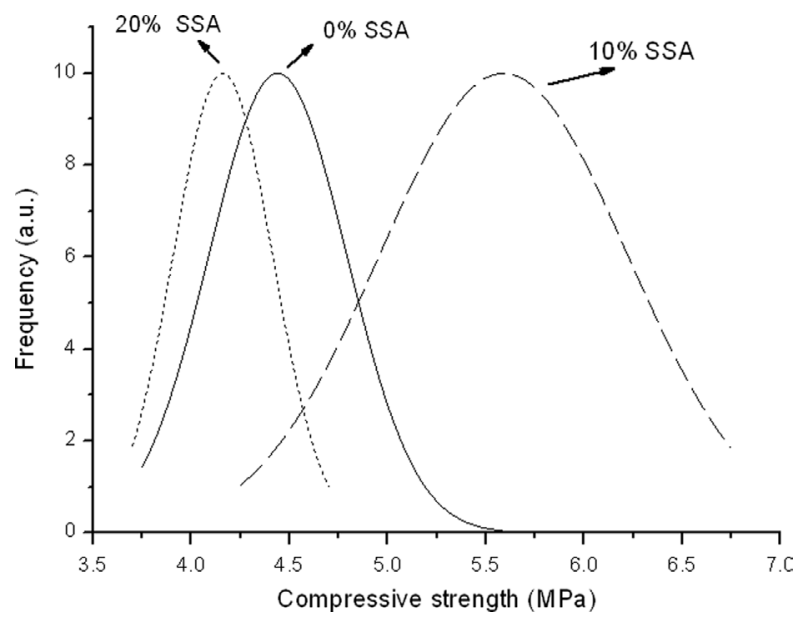

FIGURE 6. Comparison of compressive strength data distributions (normalised for height ) of pre cast concrete blocks with 0,10 and $20 \%$ SSA.

Figure 6, were: $10 \%$ for the control block, $13 \%$ for the blocks with $10 \%$ SSA and $7 \%$ for the blocks with $20 \%$ SSA. While the 10-per cent SSA blocks had slightly higher dispersion values, block uniformity was ensured, regardless of the SSA content in the material.

\subsection{Water absorption by capillarity}

Table 8 shows the water absorption values for the blocks analysed. The parameters studied $\left(\mathrm{C}_{10}\right.$ and $\mathrm{C}_{\mathrm{F}}$ ) provide information on the mass of water than can be absorbed in a given period of time (in this case, as per European standard EN 771-3,10 minutes for $\mathrm{C}_{10}$, and the end time, i.e., when mass remains constant for 15 minutes, for $\mathrm{C}_{\mathrm{F}}$ ), across the contact area defined. The findings showed that $\mathrm{C}_{10}$
TABLE 8. Water absorption by capillarity of precast concrete blocks with SSA

\begin{tabular}{lcccc}
\hline & Initial mass $(\mathbf{g})$ & $\begin{array}{c}\mathbf{C 1 0} \\
\left(\mathbf{g} \cdot \mathbf{m}^{-2} \cdot \mathbf{s}^{-0.5}\right)\end{array}$ & $\begin{array}{c}\mathbf{C F} \\
\mathbf{( g )}\end{array}$ & $\begin{array}{c}\text { DCF } \\
(\mathbf{\%})\end{array}$ \\
\hline Control & 13357 & 87 & 245 & 1.83 \\
$10 \%$ SSA & 14017 & 87 & 277 & 1.97 \\
$20 \%$ SSA & 13219 & 101 & 239 & 1.81 \\
\hline
\end{tabular}

TABLE 9. Thermal properties of pre cast concrete blocks

\begin{tabular}{lcc}
\hline & \multicolumn{2}{c}{$\begin{array}{c}\lambda \mathbf{1 0}, \mathbf{d r y} \\
\left(\mathbf{W} \cdot \mathbf{m K}^{-1}\right)\end{array}$} \\
\cline { 2 - 3 } & $\mathbf{P}=\mathbf{5 0} \%$ & $\mathbf{P}=\mathbf{9 0} \%$ \\
\hline Control & 1.136 & 1.324 \\
$10 \%$ SSA & 1.077 & 1.267 \\
$20 \%$ SSA & 1.040 & 1.230 \\
\hline
\end{tabular}

was slightly higher in the blocks with $20 \%$ SSA than in the control, while the blocks with $10 \%$ SSA exhibited the same absorption rate as the control. While $\mathrm{C}_{\mathrm{F}}$ was greater for the 10-per cent SSA blocks, their weight gain was under $2 \%$ in all cases.

\subsection{Thermal properties}

The thermal properties of the blocks were found by linear interpolation from the dry density values listed in European standard EN 771-3. The properties studied were: water vapour diffusion coefficient $(\mu)$; specific heat coefficient $(\mathrm{c})$; and thermal conductivity $\left(\lambda_{10 \text { dry }}\right)$ in the dry blocks. The $50^{\text {th }}$ and $90^{\text {th }}$ percentile values for conductivity are given in Table 9.

Given that the dry density of the blocks ranged from 2000 to $2200 \mathrm{~kg} / \mathrm{m}^{3}$ (see Table 7), no differences were observed either in the water vapour diffusion or the specific heat coefficients in any of the blocks (the values obtained were $5 / 15$ and $1 \mathrm{~J} \cdot \mathrm{g}^{-1} \cdot \mathrm{K}^{-1}$, respectively). Table 9 also shows that thermal conductivity declined with rising SSA content and that the thermal insulating properties of the blocks containing SSA rose slightly as a result of their lower density (Table 7).

\section{CONCLUSIONS}

The manufacture of pre cast concrete blocks in which the cement was replaced by up to $20 \mathrm{wt} \%$ SSA proved to be a suitable method for reducing the environmental impact of this waste material. The manufacture of blocks containing SSA to CE marking standards is commercially viable. This solution is also in keeping with the sustainability guidelines set out in Spain's National Plan for Waste Water Treatment Plant Sludge. 


\section{ACKNOWLEDGEMENTS}

This research was funded by the Spanish Ministry of the Environment under project A173/2007/304.4. The authors wish to thank Prefabricados Saval Hermanos, S.L. for the use of their pre cast concrete plant facilities to manufacture the blocks analysed in this study.

\section{REFERENCES}

1. Ministerio de Agricultura, Alimentación y Medio Ambiente: http://www.magrama.gob.es/es/calidad-y-evaluacion-ambientalltemas/prevencion-y-gestion-residuos/flujos/ lodos-depuradoral, Consulta red febrero 2013.

2. Ministerio de Medio Ambiente, y Medio Rural y Marino: Caracterización de los lodos de depuradoras generados en España. (2009).

3. Ministerio de Medio Ambiente, y Medio Rural y Marino: II Plan Nacional de lodos de depuradoras de aguas residuales. (2008) - EDAR II PNLD (2007-2015).

4. Trapote Jaume, A. (2011) Depuración de aguas residuales. Publicaciones de la Universidad de Alicante, 365-414, Alicante.

5. European Commission (2010) Environmental, economic and social impacts of the use of sewage sludge on land. Final Report. Part I: Overview Report, 3-8.

6. Cyr, M.; Coutand, M.; Clastres, P. (2007) Technological and environmental behaviour of sewage sludge ash (SSA) in cement-based materials. Cem. Concr. Res. 37, 12761289. http://dx.doi.org/10.1016/j.cemconres.2007.04.003

7. Werther, J.; Ogada, T. (1999) Sewage sludge combustion. Prog. Energ. Combust. Sci. 25, 55-116. http://dx.doi. org/10.1016/S0360-1285(98)00020-3

8. Fytili, D.; Zabanioutou, A. (2008) Utilization of sewage sludge in EU application of old and new methods - a review. Renew. Sust. Energ. Rev. 12, 116-140. http://dx.doi. org/10.1016/j.rser.2006.05.014

9. Wiebusch, B.; Seyfried, C.F. (1997) Utilization of sewage sludge ashes in the crick and tile industry. Water Sci. Technol. 36, 251-258. http://dx.doi.org/10.1016/ S0273-1223(97)00688-4

10. Anderson, M. (2002) Encouraging prospects for recycling incinerated sewagesludgeash (ISSA) into clay-based building products. J. Chem. Technol. Biot. 352-360.

11. Lin, D.F.; Chang, W.C.; Yuan, C. (2008) Production and characterization of glazed tiles containing incinerated sewagesludge. Waste Manage, 28 [3], 502-508. http://dx.doi. org/10.1016/j.wasman.2007.01.018

12. Bhatty, J.I.; Reid K.J. (1989) Compressive Strength of Municipal Sludge Ash Mortars. ACI Mater. J. 86, $394-400$.

13. Khanbilvardi, R.; Afshari, S. (1995) Sludge ash as fine aggregate for concrete mix. J. Environ. Eng.-ASCE, 121, 633-638. http://dx.doi.org/10.1061/(ASCE)0733-9372(1995)121:9(633)

14. Wainwright, P.; Cresswell, D. (2001) Synthetic aggregates from combustion ashes using an innovative rotary kiln. Waste Manage, 21, 241-246. http://dx.doi.org/10.1016/ S0956-053X(00)00096-9

15. Latosinska, J.; Zygadlo, M. (2009) Effect of sewage sludge addition on porosity of lightweight expanded clay aggregate (LECA) and level of heavy metals leaching from ceramic matrix. Environ. Prot. Eng. 35, 189-196.

16. Cheeseman, C.R.; Virdi, G.S. (2005) Properties and microstructure of lightweight aggregate produced from sintered sewage sludge ash. Resour. Conserv. Recy. 45, 18-30. http:// dx.doi.org/10.1016/j.resconrec.2004.12.006

17. Pan, S.C.; Tseng, D.H.; Lee, C. (2002) Use of sewage sludge ash as fine aggregate and pozzolan in Portland cement mortar. Journal of Solid Waste Technology and Management, $28,121-130$
18. Al Sayed, M.H.; Madany, I.M.; Buali, A.R.M. (1995) Use of sewage sludge ash in asphaltic paving mixes in hot regions. Constr. Build. Mater. 9, 19-23. http://dx.doi. org/10.1016/0950-0618(95)92856-C

19. Donatello, S.; Tong, D.; Cheeseman, C.R. (2010) Production of technical grade phosphoric acid from incinerator sewage ash (ISSA). Waste Manage. 30, 1634-1642. http://dx.doi. org/10.1016/j.wasman.2010.04.009

20. Monzó J.; Payá J.; Borrachero M.V.; Córcoles, A. (1996) Use of sewage sludge ash (SSA)-cement admixtures in mortars. Cem. Concr. Res. 26, 1389-1398. http://dx.doi. org/10.1016/0008-8846(96)00119-6

21. Monzó, J.; Payá, J.; Borrachero, M.V.; Peris, E. (1999) Mechanical Behavior of Mortars Containing Sewage Sludge Ash (SSA) and Portland Cement with Different Tricalcium Aluminate Content. Cem. Concr. Res. 29, 87-94. http://dx.doi.org/10.1016/ S0008-8846(98)00177-X

22. Alcocel, E.G.; Garcés, P.; Martínez J.J.; Payá, J.; García, L. (2006) Effect of sewage sludge ash (SSA) on the mechanical performance and corrosion levels of reinforced Portland cement mortars. Mater. Construcc. 56 [282], 31-43.

23. Payá, J.; Monzo, J.; Borrachero, M.V.; Amahjour, F.; Girbés, I.; Velázquez, S.; Ordonez, L.M. (2002) Advantages in the use of fly ashes in cements containing pozzolanic combustion residues: silica fume, sewage sludge ash, spent fluidized bed catalyst and rice husk ash. J. Chem. Technol. Biot. 77, 331-335. http://dx.doi. org/10.1002/jctb.583

24. Donatello, S.; Tyrer, S.; Cheeseman, C.R. (2010) Comparison of test methods to assess pozzolanic activity. Cem. Concr. Comp. 32, 121-127. http://dx.doi.org/10.1016/j. cemconcomp.2009.10.008

25. Pan, S.C.; Tseng, D.H.; Lee, C.C.; Lee, C. (2003) Influence of the fineness of sewage sludge ash on the mortar properties. Cem. Concr. Res. 33, 1749-1754. http://dx.doi. org/10.1016/S0008-8846(03)00165-0

26. Monzó, J.; Payá, J.; Borrachero, M.V.; Girbés, I. (2003) Reuse of sewage sludge ashes (SSA) in cement mixtures: the effect of SSA on the workability of cement mortars. Waste Manage. 23, 373-381. http://dx.doi.org/10.1016/ S0956-053X(03)00034-5

27. Donatello, S.; Freeman-Pask, A.; Tyrer, S.; Cheeseman, C.R. (2010) Effect of milling and acid washing on the pozzolanic activity of incinerator sewage sludge ash. Cem. Concr. Comp. 32, 54-61. http://dx.doi.org/10.1016/j. cemconcomp.2009.09.002

28. Chen, C.-H.; Chiou, I.-J.; Wang, K.-S. (2006) Sintering effect on cement bonded sewage sludge ash. Cem. Concr. Comp. 28, 26-32. http://dx.doi.org/10.1016/j. cemconcomp.2005.09.003

29. Garcés, P.; Carrión, M.P.; García-Alcocel, E.; Payá, J.; Monzó, J.; Borrachero, M.V. (2008) Mechanical and physical properties of cement blended with sewage sludge ash. Waste Manage, 28, 2495-2502. http://dx.doi.org/10.1016/j. wasman.2008.02.019

30. Pérez-Carrión, J.M.; Garcés, P. García, E.; Payá, J.; Monzó, J.; Borrachero, M.V. (2005) Hormigonesecológicos (green concrete): reutilización de cenizas de lodos de depuradora en la preparación de hormigones. Actas VI Congreso Nacional de Materiales Compuestos, 27-29 June, Valencia (Spain).

31. Lapa, N.; Barbosa, R.; Lopes, M.H.; Mendes, B.; Abelha, P.; Gulyurtlu, I.; Santos-Oliveira, J.S. (2007) Chemical and ecotoxicological characterization of ash esobtained from sewage sludge combustión in a fluidised bed reactor. J. Haz. Mat. 147, 175-183.

32. Donatello, S.; Tyrer, M.; Cheeseman, C.R. (2010) EU landfill waste acceptance criteria and EU Hazardous Waste Directive compliance testing of incinerated sewage sludge ash. Waste Manage. 30, 63-71. http://dx.doi.org/10.1016/j. wasman.2009.09.028 